\title{
Doklady redepozice kř́dových sedimentů do uloženin spodního miocénu mezi Černou Horou a Závistí
}

Evidence of reworked Cretaceous sediments in the lower Miocene deposits between Černá Hora town and Závist village

\author{
Jiří Otava $\neg$, Miroslav Bubík, Pavla Tomanová Petrová, Oldřich Krejčí, \\ Vladimíra Krejčí, Libor Potůček, Irena Sedláčková
}

'Česká geologická služba, Leitnerova 22, 65869 Brno, Česká republika

${ }_{2}^{2}$ SAFETY PRO s.r.o., Veveří 2581/102, 61600 Brno, Česká republika

Key words:

Bohemian Massif, Ottnangian, Cretaceous, boreholes, translucent heavy mineral assemblages, Foraminifera, redepositions, landslides

$\varpi$ jiri.otava@geology.cz

Editor:

Martin Ivanov

\begin{abstract}
Many boreholes have been drilled between Černá Hora town and Závist village to evaluate geohazards that may affect the construction of a new road. The core material from boreholes was studied for translucent heavy minerals and microfossil content. Translucent heavy mineral assemblages from sands are often dominated by the staurolite. Cyanite, tourmaline, rutile and andalusite, typical for Cenomanian sediments of Moravia are common. Relatively important share of garnet (20-30\%) in two samples reflects most probably the source in Turonian sediments. Those heavy minerals typical for granitoids of the Brno Massif, surrounding and underlying the sediments, are very rare. Agglutinated foraminifera reworked from Turonian or younger Cretaceous sediments, represent the most frequent microfossils. Single find of Pleurostomella gr. alternans may be the only autochthonous element indicating the Miocene age. Both microfossils and translucent heavy mineral assemblages correspond with those from previously studied sites of broader area including Brno surroundings. Sediments are characterised by a high susceptibility to sliding, which was particularly evident during the high rainfall totals in spring 2006.
\end{abstract}

Úvod, historie výzkumů, geologie širšího okolí

V zájmové oblasti se nacházejí pouze kvartérní a miocenní sedimenty uložené na magmatitech brněnského masivu, technické práce související s výše uvedenou stavbou upřesnily její geologické znalosti.

Během technických průzkumných prací pro stavby „I/43 Lom Černá Hora“ a „I/43 Závist, stoupací pruh“, které jsou součástí souboru stavebních úprav silnice I/43 v úseku Milonice - Černá Hora (Bulgurovská - Potůček 2020), bylo odvrtáno mnoho vrtů do hloubky $20 \mathrm{~m}$, jejichž primárním účelem bylo mimo jiné vyhodnotit stav sesuvných území v trase silnice a jejím ochranném padesátimetrovém pásmu (obr. 1). Inženýrskogeologický průzkum zajištovala společnost SAFETY PRO s.r.o., Brno.

O sedimentech mezi Černou Horou a Závistí se stručně zmiňuje Ř́kovský (1929). Ve své práci cituje mapu a vysvětlivky (Tausch 1898) a v podstatě správně dedukuje, že štěrky a písky této oblasti přinesl paleotok, který ve spodním miocénu přitékal ze $S$ od Boskovické brázdy.

Popisovaná oblast byla v 70. letech 20 . století předmětem výzkumu v rámci tzv. „Státního výzkumného úkolu Katedry geologie a palontologie týkajícího se karpatské předhlubně a výběžků a ostrůvků miocénu na Českém masivu“. Výsledky tehdy zpracovaných tří diplomových prací (Procházka 1973; Zachová 1973; Otava 1973) lze stručně shrnout poznámkou, že veškeré miocenní sedimenty 
mapované $\mathrm{v}$ rámci polygonu Tišnov - Lomnice - Černá Hora - Lipůvka - Tišnov byly tehdy řazeny ke spodnímu badenu lanzendorfské série. Tyto závěry pak byly potvrzeny v geologické mapě Krystka (1973) - (mapován byl pouze terciérní pokryv). Procházka (1973) však v závěrech práce nevyloučil, že se může jednat o sedimenty spodního miocénu, chyběly však pro to důkazy. Další výzkumy postupně ukazovaly, že sedimentaci mořského badenu na mnoha místech předcházela sedimentace brakického a sladkovodního ottnangu. Pro zájmovou oblast je tento problém podrobněji rozveden v práci Petrové et al. (2001) a pro bezprostřední j. okolí u Svinošic a Šebrova (Vít 1998). V geologické mapě v měŕitku $1: 25000$, na listu 24-322 Blansko, Hanžl et al. (2007) již správně zařadili izolované výskyty těchto sedimentů k ottnangu. Většina zájmového území však byla zmapována pouze přehledně do měřítka 1: 50000 (Nekovařík et al. 1991; Hanžl et al. 1999). Hanžl et al. (2019) publikovali schematickou mapu oblasti brněnského masivu mezi Brnem a Černou Horou. V rámci prací vyhledávacího průzkumu na molybdenit (Almassy et al. 1985) byla plošně zmapována a vrtně ověřena s. část zájmového území z hlediska výskytu terciérního a kvartérního pokryvu (obr. 1).

Sedimenty miocénu širšího okolí Brna vystupují v podobě výplní starých údolí a rovněž jako denudační relikty diskordantně překrývající horniny brněnského masivu, paleozoika či mezozoika. Místy se jedná o tektonicky zaklesnuté zbytky menších sedimentačních prostorů (Krejčí et al. 2021). V rámci facií ottnangu jsou na Brněnsku známy šedé až zelenavé, místy vápnité i nevápnité jíly, písky a petromiktní štěrky, jílovitopísčité štěrky s polohami

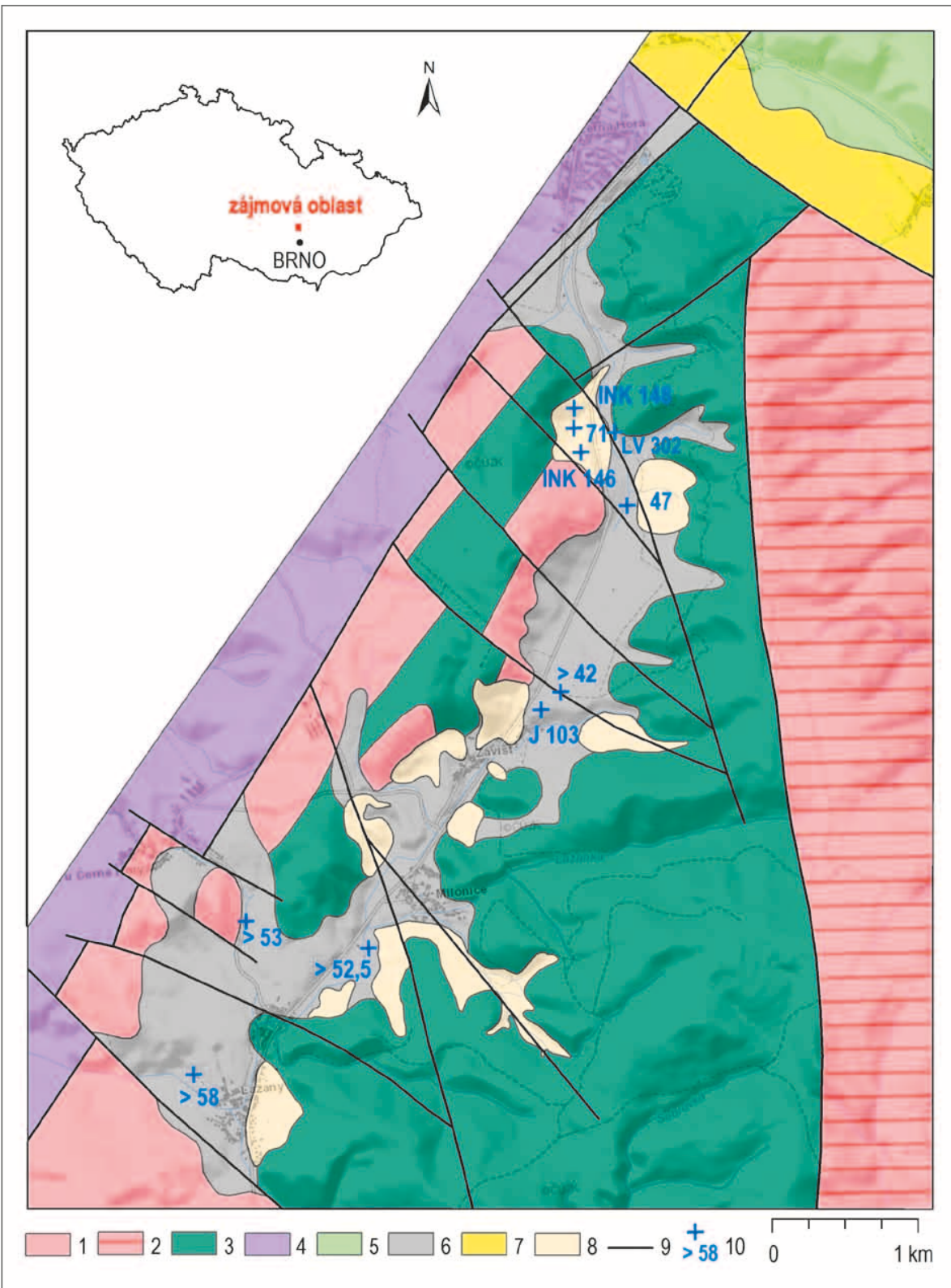

Obr. 1: Geologická mapa zkoumaného území bez kvarterních sedimentů se sesuvy. Předterciérní podklad upraven podle Geologické mapy 1:50 000 (Nekovař́ík et al. 1991). Legenda: Brněnský masiv: 1 - západní granodioritová zóna včetně paleozoického pokryvu; 2 - východní granodioritová zóna; 3 - dioritová a metabazitová zóna. Platformní pokryv: 4 - sedimenty permokarbonu boskovické brázdy; 5 - sedimenty české kř́dové pánve; 6 - sedimenty ottnangu; 7 - sedimenty badenu; 8 - sesuvy; 9 - zlomy; 10 - vrty se zastiženou mocností sedimentů ottnangu. Vrty z roku 2021 s odebranými vzorky J103, INK 146 a INK 148.

Fig. 1: Geological map of the studied area without Quaternary sediments with landslides. Pre-tertiary basement modified according to the Geological Map 1:50 000 (Nekovařík et al. 1991). Legend: Brno Massif: 1 - Western Granodiorite Complex; 2 - Eastern Granodiorite Complex; 3 - Diorite and Metabasite Zones. Platform cover: 4 - Permian and Carboniferous sediments of the Boskovice furrow; 5 - Bohemian Creataceous Basin sediments; 6 - Ottnangian sediments; 7 - Badenian sediments; 8 - landslides; 9 - faults; 10 - boreholes; Ottnangian sediments thickness. Boreholes from 2021 with rock samples J103, INK 146 and INK 148.

jílů a jemnozrnné písky s klasty granodioritů. Průsvitná těžká frakce těchto sedimentů se pravidelně vyznačuje značným zastoupením staurolitů (Nehyba et al. 2007; Hanžl et al. 2020; Buriánek et al. 2012). Jíly často obsahují pseudoasociace mikrofosilií tvořené redeponovanými foraminiferami a úlomky jehlic hub. Foraminifery jsou 
redeponované $\mathrm{z}$ pelitických sedimentů turonu-coniaku nejasné provenience (Nehyba et al. 2007).

\section{Metodika, vzorkování Mapování, posouzení sesuvi̊}

Po sestavení geologické mapy 1 : 25000 (Hanžl et al. 2007) v j. části zájmového území bylo podrobné mapování v této oblasti ukončeno. Vlivem vysokých úhrnů deštových srážek v roce 2006 došlo na sedimentech spodního miocénu podél silnice I/43 ke vzniku několika sesuvů (sesuvy 24-14-24/1a, 4a, 6; 24-32-04/4a - obr. 2A). Postupně během jejich terénní revize byly na těchto sedimentech zjištěny další sesuvy v okolí (24-14-24/1, 2, 3, 4, 5, 6 - obr. 2B, 7, 10, 11; 24-32-04/3, 4, 5). Sesuvy jsou evidovány a popsány $\mathrm{v}$ Registru svahových nestabilit (https://mapy.geology.cz/svahove_nestability/).

Na sesuvech je zajímavé to, že nevznikly na svahových sedimentech, ale prrímo na podkladu spodnomiocenních sedimentů (obr. 2C, 2D). Spodnomiocenní sedimenty se vyznačují vysokou náchylností k sesouvání a to i na svazích s relativně nízkým sklonem (5 až $10^{\circ}$ ). Sesuvy byly proto zahrnuty do mapy zkoumané oblasti bez kvartérního pokryvu (obr. 1).
Na sesuvu 24-14-24/5 byly v roce 2021 odvrtány inklinometricky vystrojené vrty INK 146 a INK 148 hluboké $20 \mathrm{~m}$. Během těchto terénních prací bylo postupně vymezeno celé území výskytu spodnomiocenních sedimentů (obr. 1), které jsou j. od Lažan omezeny bezejmenným zlomem a na S jsou omezeny okrajovým zlomem blanenského prolomu (Zvejška 1944). Pro detailní vymezení těchto sedimentů byl využit digitální model reliéfu 5G pro ČGS smluvně zajištěný z ČÚZK, archivní podklady z ČGS (ASGI) včetně databáze vrtné prozkoumanosti (https://mapy.geology.cz/vrtna_prozkoumanost/). Výskyt spodnomiocenních sedimentů na brněnském masivu je vázán na zlomově omezenou oblast. Svědčí o tom relativně vysoké mocnosti sedimentů v blízkosti okrajů jejich výskytu, napŕíklad 71,5 m ve vrtu LV 302 (obr. 3) na sesuvu 24-14-24/5 (Almassy et al. 1985). Pouze v nejsevernější části leží v jejich podloží sedimenty permokarbonu boskovické brázdy. V severním, západním a jižním okolí námi studovaného výskytu sedimentů spodního miocénu jsou známy na povrchu pouze uloženiny badenu, na V se nachází elevační oblast brněnského masivu.
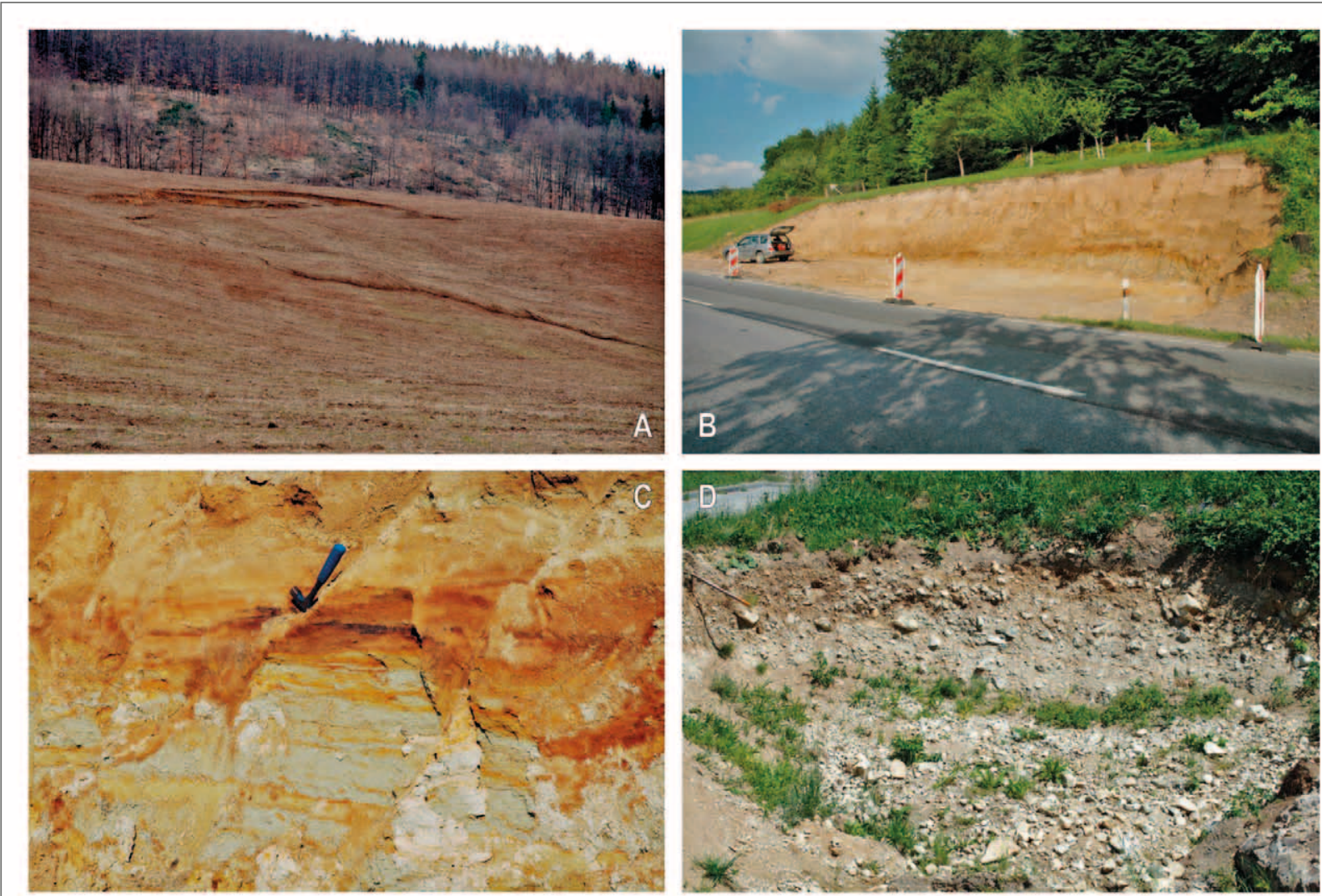

Obr. 2: A - Celkový pohled na sesuv č. 24-32-04/4a po jeho vzniku v roce 2006 v Milonicích u Lipůvky, délka sesuvu $120 \mathrm{~m}$, šíŕka 75 m; B - Pohled na odkryté čelo sesuvu č. 24-14-24/6 po jeho vzniku v roce 2006 v Závisti, šířka odkrytého zářezu je 50 m; C - Litologický profil sedimenty ottnangu v čele sesuvu č. 24-14-24/6 v Závisti; D - Ostrohranné hrubě klastické sedimenty ottnangu v čele sesuvu č. 24-34-04/2 v Lažanech, šírka snímku je asi 3,5 m.

Fig. 2: A - General view of the slide No. 24-32-04/4a after its formation in 2006 in Milonice nearby Lipůvka village, landslide length $120 \mathrm{~m}$, width $75 \mathrm{~m}$; B - A view of the exposed toe of the landslide 24-14-24/6 after its formation in 2006 in Závist village, the width of the exposed wall is $50 \mathrm{~m}$; C - Lithological profile of Ottnangian sediments in the toe of the landslide No. 24-14-24/6 in Závist village; D - Sharply angular coarse grained sediments of the Ottnangian age in the toe of the landslide No. 24-32-04/2 in Lažany village, the width of the image is about $3.5 \mathrm{~m}$. 
Mikropaleontologie, analýzy průsvitných těžkých minerálů, odběryvzorků Zpracovávána byla jádra tř́ vrtů (tab. 1) a to dvou inklinometrických vrtů odvrtaných pro sledování sesuvu (INK 146 a INK 148) a jednoho průzkumného (J 103). Z vrtných jader byly odebrány dva vzorky, které byly určeny $\mathrm{k}$ paleontologickému studiu a tři vzorky ke studiu průsvitných těžkých minerálů.

Pro paleontologická studia byly vzorky namočeny do roztoku jedlé sody a vyplaveny standardními metodami na sítech o velikosti $2 \mathrm{~mm}, 0,9$ a $0,063 \mathrm{~mm}$. Fauna z výplavů byla zkoumána a identifikována pod optickým mikroskopem NIKON SMZ 745T.

Pro studium průsvitné těžké frakce byly separovány po odplavení jílovité frakce vzorky písku sítované na interval 0,06-0,25 $\mathrm{mm}$. Z nich vznikla v laboratořích ČGS Brno těžká frakce separovaná v LST (heteropolywolframan lithný), měrná hmotnost $2,96 \mathrm{~g} . \mathrm{cm}^{-3}$. Průsvitná těžká frakce byla určována a vyhodnocována v mineralogickém mikroskopu Amplival. Procentuální zhodnocení se týká počtu zrn bez ohledu na hmotnost či velikost zrn.

\section{Výsledky \\ Paleontologie}

Vzorky z vrtů INK 146 a INK 148 obsahovaly relativně četnou mikrofaunu s obdobným složením. Zcela převažují aglutinované foraminifery a četné jsou úlomky jehlic hub. Trubicovité aglutinované foraminifery jsou fragmentární a dají se s určitými pochybnostmi přiřadit $\mathrm{k}$ rodům Rhizammina, Saccorhiza a Hyperammina, i když diagnostické znaky chybí. Nehojně jsou zastoupeny astrorhizidi Psammosphaera sp. a ammodiscidi Glomospira irregularis (Grz.) a Glomospira sp. Hojní jsou různí lituolidi: Ammobaculites tyrelli N., A. cf. obscurus L., Haplophragmoides decussatus K., H. porrectus M., Recurvoides retroseptus (Grz.), Plectorecurvoides parvus K., Ammosphaeroidina sp. Další komponentou foraminiferové fauny jsou Spiroplectammina navarroana (C.), Karrerulina conversa (Grz.), K. stanislavi N., K. horrida (M.), Trochammina sp. a nehojní verneuilinidi Arenobulimina orca V., A. cf. brevicona (P.) a Pernerina depressa (P.). Vyloužená minerální jádra jednotlivých subsférických komůrek ukazují pravděpodobně na původní prítomnost planktonických foraminifer. Ve vzorku z vrtu INK 148 se vyskytl zcela ojedinělý exemplář značně poškozeného zástupce rodu Pleurostomella $\mathrm{z}$ okruhu Pleurostomella alternans $\mathrm{S}$. Tento exemplář má dobře zachovanou stěnu schránky nepostiženou diagenezí a je velmi pravděpodobně mladšího stáŕí, nežli výše vyjmenované fosilie (miocén?).

\section{Asociace průsvitných těžkých minerálů}

Zjištěnou asociaci průsvitných těžkých minerálů (obr. 4) lze označit $\mathrm{v}$ př́padě vrtu INK 146, hloubka $16,5 \mathrm{~m}$ jako zirkon-rutil-kyanit-turmalín-staurolitovou, přičemž dominující staurolit tvoří téměř $2 / 3$ asociace. Akcesoricky je zastoupen sillimanit, granát, andalusit, apatit, monazit, alterit, sagenit, amfibol, chromspinel. Index zralosti asociace (součet obsahů ultrastabilních minerálů zirkonu, turmalínu a rutilu) ZTR je u tohoto vzorku 22,8 . Poněkud jiné složení mají dva vzorky z vrtů INK 148 a J 103. U nich je hlavním rozdílem vyšší (20-30\%) zastoupení granátů. Index zralosti ZTR u těchto vzorků je výrazně nižší, ultrastabilní minerály (zirkon, turmalín a rutil) byly evidentně nahrazeny právě granátem, jak je zřejmé z tabulky 1 a obrázku 4. Navzdory této odlišnosti v kvantitativním složení asociací není mezi vzorky téměř žádný rozdíl ve spektru zastoupených minerálů.

Obr. 3: Profil vrtem LV 302 a předvrtem MV 130. Legenda: 1 - kvartérní hlíny; 2 - šedé jílovité písky; 3 - jíly, místy písčité; 4 - granity brněnského masivu; 5 - nerozlišené horniny brněnského masivu.

Fig. 3: Profile of the borehole LV 302 and advance borehole MV 130. Legend: 1 - Quarternary soils; 2 - gray clay sands; 3 - clays, sometimes sandy; 4 - granites of the Brno Massif; 5 - undifferentiated rocks of the Brno Massif.

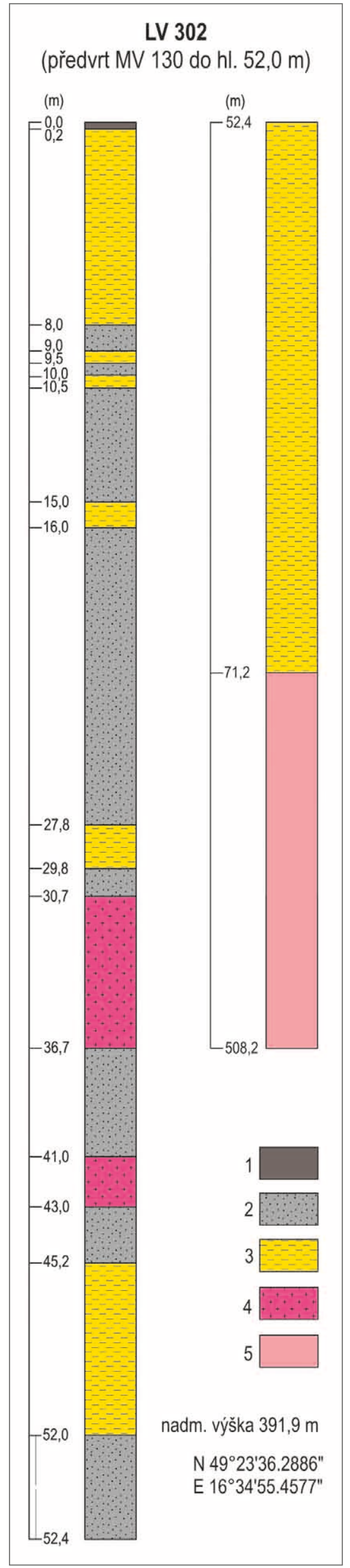


Tab. 1: Složení průsvitné těžké frakce písků z vrtů. Tab. 1: Composition of translucent heavy mineral assemblages from boreholes.

\begin{tabular}{|c|c|c|c|}
\hline VRT & INK 146 & INK 148 & J 103 \\
\hline souřadnice & $\begin{array}{l}\mathrm{N} 49^{\circ} 23^{`} 34.7901^{\prime \prime} \\
\mathrm{E} 16^{\circ} 34^{‘} 58.2962^{\prime \prime}\end{array}$ & $\begin{array}{l}\mathrm{N} 49^{\circ} 23^{`} 42.5645^{\prime \prime} \\
\text { E } 16^{\circ} 34^{\prime} 54.0221^{\prime \prime}\end{array}$ & $\begin{array}{l}\text { N } 49^{\circ} 22^{`} 41.4521^{\prime \prime} \\
\text { E } 16^{\circ} 34^{\prime} 36.6990^{\prime \prime}\end{array}$ \\
\hline hloubka (m) & 16,50 & 17,80 & 5,60 \\
\hline granát & 1,40 & 30,20 & 20,30 \\
\hline zirkon idi. & 2,90 & 0,20 & 0,30 \\
\hline zirkon oval. & 4,80 & 0,20 & 0,50 \\
\hline apatit & 0,70 & 0,20 & 0,30 \\
\hline rutil & 7,90 & 1,00 & 1,30 \\
\hline turmalín & 7,20 & 4,00 & 1,60 \\
\hline epidot & 0,00 & 0,00 & 2,30 \\
\hline staurolit & 63,50 & 55,30 & 67,50 \\
\hline amfibol & 0,30 & 0,50 & 0,00 \\
\hline kyanit & 7,70 & 3,70 & 2,10 \\
\hline alterit & 0,50 & 0,00 & 0,00 \\
\hline andalusit & 0,50 & 3,00 & 1,80 \\
\hline chromspinel & 0,30 & 0,20 & 0,00 \\
\hline sagenit & 0,50 & 0,20 & 0,30 \\
\hline monazit & 0,50 & 0,00 & 0,30 \\
\hline ostatní & 1,30 & 1,30 & 1,40 \\
\hline
\end{tabular}

\section{Interpretace, diskuze a závèr}

V oblasti mezi Černou Horou a Závistí, $20 \mathrm{~km}$ s. od Brna, byly $\mathrm{z}$ vrtů nově popsány pestré sedimenty miocénu. Z hlediska zrnitosti jsou sedimenty klasifikovány jako jílovitý prach, středně až hrubě zrnité písky, valounové písky a štěrky, vesměs velmi špatně vytříděné.

Sedimenty se vyznačují vysokou náchylností ke vzniku sesuvů, což se projevilo především během vysokých úhrnů srážek na jaře 2006.

Absence autochtonní fauny a výskyt redeponovaných kř́lových aglutinovaných druhů spolu s úlomky jehlic hub indikují ottnangské stáŕí sedimentů. Podobné pseudoasociace jsou pro sedimenty ottnangu na Brněnsku typické (Nehyba et al. 2007). Druhy aglutinovaných foraminifer Plectorecurvoides parvus K., Spiroplectammina navarroana (C.), Karrerulina conversa (Grz.), K. stanislavi N., K. horrida (M.), Pernerina depressa (P.) dovolují stratigrafické zařazení zdrojových sedimentů $\mathrm{v}$ rámci intervalu turon-santon. $\mathrm{V}$ každém př́ípadě jsou všechny redeponované. $Z$ provenienčního hlediska lze mezi aglutinovanými foraminiferami najít druhy známé z turonu až eocénu karpatského flyše a nezaznamenané v sedimentech české kř́ldové pánve: Haplophragmoides decussatus K., H. porrectus M., Recurvoides retroseptus (Grz.), Plectorecurvoides parvus K., Spiroplectammina navarroana (C.). Jsou ale rovněž prítomny druhy běžné v cenomanu až coniaku české

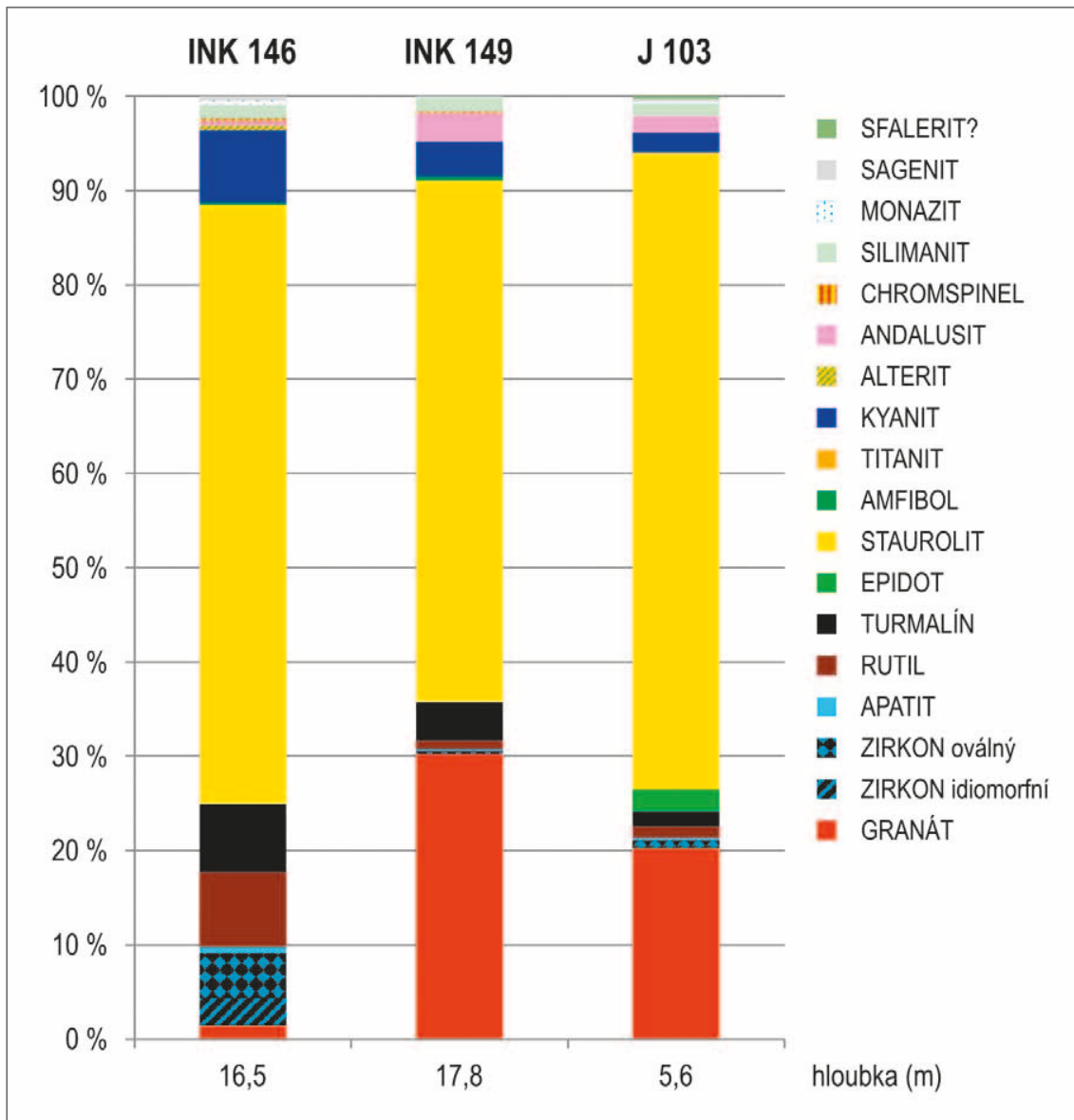

Obr. 4 : Srovnání asociací průsvitných těžkých minerálů (\%) písků ze studovaných vrtů lokality Závist (k. ú. Černá Hora).

Fig. 4: Comparison of translucent heavy mineral assemblages (\%) in sands of studied boreholes, Závist site (c. t. Černá Hora). kř́́dové pánve a jen omezeně rozšiřené v karpatském flyši: Arenobulimina spp., Pernerina depressa (P.). Znalost rozšíření aglutinovaných foraminifer zejména $\mathrm{v}$,české kř́iě je dosud natolik nedostatečná, že na jednoznačné provenienční závěry je zatím brzo. V každém př́ípadě byly podobné redeponované křídové fauny zaznamenány $\mathrm{v}$ píscích $\mathrm{z}$ Lomnice u Tišnova a Bělče a $z$ brakických až lakustrinních litofacií ottnangu v Brně a okolí (např. Bubík 1993, 1997; Nehyba et al. 2006; Krejčí et al. 2021). Za jediný autochtonní prvek je možné považovat ojedinělý exemplář Pleurostomella gr. alternans S. z vrtu INK 148, který ukazuje na miocénní stáří sedimentů.

$\mathrm{V}$ průsvitné těžké frakci dominuje staurolit, následován u části vzorků minerály skupiny granátů. Dále je zastoupen zirkon, rutil, kyanit, turmalín, sillimanit, andalusit a v akcesorickém množství též minerály skupiny amfibolů, epidotů, monazit, chromspinel, apatit. Takovéto asociace jsou z širšího okolí 


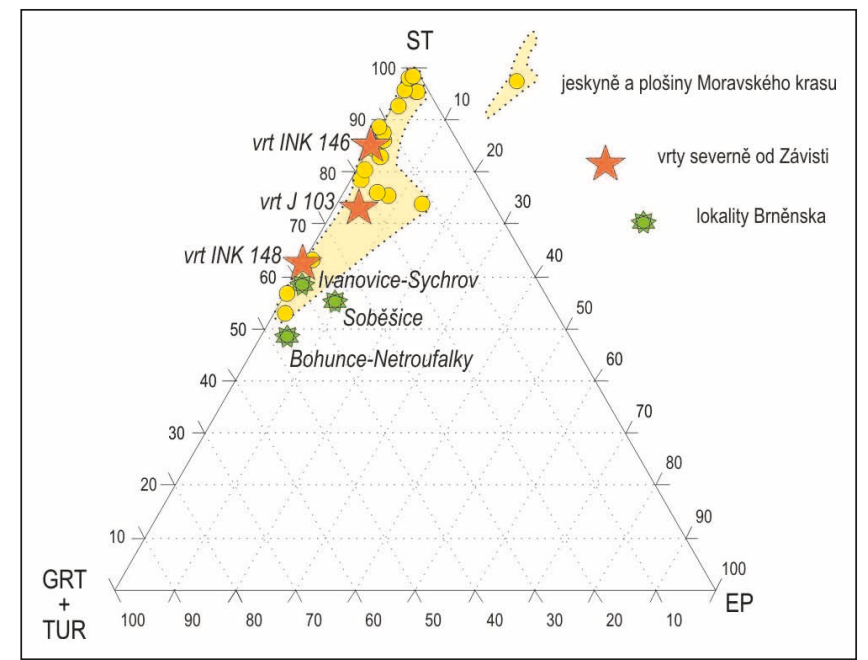

Obr. 5: Srovnání asociací průsvitných těžkých minerálů v pískách studovaných vrtů s asociacemi v ottnangu Moravského krasu a Brněnska.

Fig. 5: Comparison of translucent heavy mineral assemblages of sands from studied boreholes with associations in Ottnangian of the Moravian Karst and Brno Region. Yellow - caves and plains of the Moravian Karst; red stars - boreholes N from Závist Village; green - sites of the Brno Region.

studované lokality známy již dlouhou dobu (Procházka 1973; Petrová et al. 2001; Nehyba et al. 2007; Otava 2010). Vyjmenované minerály pocházejí nejpravděpodobněji především z křídových sedimentů blízkého okolí a to jak ze sedimentů cenomanu, tak i z usazenin turonu (viz zastoupení granátů, tab. 1), event. coniaku. Z toho plyne, že zdroj detritického materiálu byl stejný nebo velmi podobný. Hlavním rozdílem je vyšší (20-30\%) zastoupení granátů. Index zralosti ZTR, tedy procentuální zastoupení utrastabilních minerálů zirkonu, turmalínu a rutilu, je u těchto vzorků výrazně nižší (viz tab. 1). Ultrastabilní minerály (zirkon, turmalín a rutil) byly evidentně nahrazeny právě granátem. Navzdory této odlišnosti v kvantitativním složení asociací není mezi vzorky téměř žádný kvalitativní rozdíl. Kvantitativní rozdíly lze přičíst různému stupni mechanického a chemického vytř́íění sedimentu, což odráží i obecně popisovanou špatnou vytrríděnost usazenin. Určitým překvapením je zcela nepatrné zastoupení typomorfních minerálů (amfibol, epidot, titanit) granitoidů brněnského masivu, který tvoří podloží a bezprostřední okolí analyzovaných sedimentů. Srovnáme-li asociace studovaných písků z vrtů s. od Závisti s Moravským krasem (Otava 2017) a Brněnskem (Hanžl ed. 2020; Nehyba et al. 2007), lze pozorovat téměř dokonalou podobu především s písky plošin a výše položených jeskyní Moravského krasu (obr. 5).

\section{Poděkování}

Předložená práce vznikla za finanční podpory interního projektu České geologické služby číslo 321070 (Registr svahových nestabilit), který je součástí DKRVO/ČGS (2018-2022), oblast výzkumu 5: Výzkum geologických rizik. Dík patř́ rovněž společnosti SAFETY PRO s.r.o., za umožnění odebrání a zpracování vzorkư z vrtů a v neposlední řadě handling editorovi. Jsme zavázáni obèma recenzentům Janu Vítovi a Slavomíru Nehybovi za zkvalitnění príspěvku a pečlivé korektury. 


\section{Literatura}

Almassy, J., Chocholíková, J., Cimbálník, V., Červenka, J., Drábek, M., Kolčava, D., Kolek, P., Kraus, L., Slavík, D., Staňková, J., Šponar, J., Štancl, R., Trnka, M., Vašinová, J., Životský, J. (1985). Závěrečná zpráva Černá Hora - Mo rudy. Surovina: Mo rudy. Etapa: vyhledávací průzkum. - ČGS Praha. 93 str. P033363.

Bubík, M. (1993). Nové výsledky mikropaleontologického studia miocénu v Brně-Líšni. - Geologické výzkumy na Moravě a ve Slezsku, 26, 15-16.

Bubík, M. (1997). O miocénu z vrtů na trase vodovodního přivaděče Vír-Brno. - Zprávy o geologických výzkumech v roce 1996, 29, 64-66.

Bulgurovská, M., Potůček, L. (2020). I/43 Lom Černá Hora, přeložka, podrobný geotechnický průzkum, realizační projekt prací. - MS GEOtest, a.s.

Buriánek, D., Tomanová Petrová, P., Otava, J. (2012). Kde je zdroj klastických sedimentů miocénu brněnska? - Acta Musei Moraviae, Scientae geologicae XCVII, 1, 153-166.

Hanžl, P., Krejčí, Z., Vít, J., Otava, J., Novák, Z., Stráník, Z. (1999). Geologická mapa Brna a okolí. - Český geologický ústav Praha.

Hanžl, P., Čech, S., Čtyroká, J., Čurda, J., Gilíková, H., Hradecká, L., Hubatka, F., Janoušek, V., Kašpárek, M., Manová, M., Maštera, L., Otava, J., Tomanová Petrová, P., Šalanský, K., Šrámek, J., Vít, J., Hrdličková, K. (2007). Základní geologická mapa České republiky 1:25000 s Vysvětlivkami, list 24-322 Blansko. Česká geologická služba, Praha, 1-70.

Hanžl, P., Baldík, V., Bubík, M., Buriánek, D., Dolníček, Z., Dvořák, I. J., Fürychová, P., Havlín, A., Hrdličková, K., Kociánová, L., Konečný, F., Krejčí, O., Krejčí, Z., Krumlová, H., Kryštofová, E., Müller, P., Paleček, M., Pecina, V., Pecka, T., Poul, I., Rez, J., Skácelová, D., Skácelová, Z., Slobodník, M., Šrámek, J., Tomanová Petrová, P., Večeřa, J., Vít, J. (2020). Vysvětlivky k základní geologické mapě České republiky $1: 25$ 000, 24-324 Brno-sever. - ČGS. Praha.

Hanžl, P., Janoušek, V., Soejono, I., Buriánek, D., Svojtka, M., Hrdličková, K., Erban, V., Pin, Ch. (2019). The rise of the Brunovistulicum: age, geological, petrological and geochemical character of the Neoproterozoic magmatic rocks of the Central Basic Belt of the Brno Massif. - International Journal of Earth Sciences, 108, 1165-1199. https://doi.org/10.1007/s00531019-01700-2

Krejčí, O., Bubík, M., Buriánek, D., Doláková, N., Krejčí, V., Nehyba, S., Tomanová Petrová, P., Vít, J. (2021). Kenozoické sedimenty v lomu Předklášteří u Tišnova. - Geologické výzkumy na Moravě a ve Slezsku, 27, 1-2, 20-32. https://doi.org/10.5817/ GVMS2021-14408

Krystek, I. (1973). Geologická mapa $1: 25000$ M-33-94-C-c Černá Hora. - MS Archiv Česká geologická služba. MO 17.

Nehyba, S., Bubík, M., Kirchner, K., Petrová, P., Vít, J. (2006). Fluviální sediment mezi Jinačovicemi a Kuřimí. - Geologické výzkumy na Moravě a ve Slezsku v roce 2005, 44-47.

Nehyba, S., Otava, J., Bubík, M., Tomanová Petrová, P., Kirchner, K. (2007). Miocénní sedimenty v Brně-Bohunicích (ubytovna Fakultní nemocnice Brno). - Geologické výzkumy na Moravě a ve Slezsku v roce v r. 2006, 14, 31-34.

Nekovařík, Č., Jaroš, J., Mitrenga, P., Rejl, L., Smolíková, L., Zelenka, P., Zeman, A. (1991). Geologická mapa ČR 1 : 50000 , list 24-14 Boskovice. - Český geologický ústav Praha.

Otava, J. (1973). Mapování miocenních ostrůvků listu Tišnov M-33-93-D-d. - MS. Dipl. Práce. Katedra geologie a paleontologie, PřF UJEP. Brno.

Otava, J. (2010). Těžké minerály kenozoika Brněnska - možnosti a úskalí interpretací. - Geologické výzkumy na Moravě a ve Slezsku, 17, 1-2, 81-84.

Otava, J. (2017). Tracing the origin of cave sands: State of the art in the Moravian Karst. - In: Moore, K., White, S. (eds). Proceedings of the 17th International Congress of Speleology, July 22-28, Sydney, NSW Australia. Volume 2, 512-515, Australian Speleological Federation Inc. Sydney.

Petrová, P., Vít, J., Čtyroká, J. (2001). Okrajové vývoje sedimentů karpatské předhlubně na listech map $1: 25000$ Blansko a Tišnov. - Scripta Facultatis Scientiarum Naturalium Universitatis Masarykianae Brunensis, Vol. 30, Geology. 55-64. Brno.

Procházka, Z. (1973). Mapování miocenních ostrůvků na listě mapy M-33-94-C-c. - MS. Dipl. Práce. Katedra geologie a paleontologie, PřF UJEP. Brno.

Říkovský, F. (1929). Paleopotamologický vývoj Svitavy. - Sborník Státního geologického ústavu, VIII, 257-304.

Tausch, L. v. (1898). Geol. Spezialkarte und Erlauterungen zur geol. Karte Blatt Boskowitz und Blansko. Wien

Vít, J. (1998). Tercierní údolí v okolí Šebrova a Svaté Kateřiny. - Acta Musei Moraviae, Scientiae Geologiae. 83, $109-113$.

Zachová, V. (1973). Mapování miocenních ostrůvků na listě mapy M-33-94-C-a. - MS. Dipl. Práce. Katedra geologie a paleontologie, PřF UJEP. Brno.

Zvejška, F. (1944). Blanenský prolom. - Práce Moravské př́rodovědecké společnosti, 16, 1, F159. Pp. 28.

Internetové zdroje:

https://mapy.geology.cz/svahove_nestability/

https://mapy.geology.cz/vrtna_prozkoumanost/ 